\title{
THE IMPACT OF DIGITAL PRINTING MACHINES ON INDOOR AIR QUALITY
}

\author{
Savka Adamović ${ }^{1}$ (D), Ivan Pinćjer ${ }^{1}$ (D), Dragan Adamović ${ }^{2}$ (D), \\ Vladimir Zorić ${ }^{1}$, Stefan Đurđević ${ }^{1}$ \\ ${ }^{1}$ University of Novi Sad, Faculty of Technical Sciences, \\ Department of Graphic Engineering and Design, Novi Sad, Serbia \\ ${ }^{2}$ University of Novi Sad, Faculty of Technical Sciences, Department of Environmental \\ Engineering and Occupational Safety and Health, Novi Sad, Serbia
}

\begin{abstract}
The objective of the study is to evaluate the indoor air quality in digital printing facility during the three working weeks (120 hours). For that purpose, mass concentrations of suspended particulate matter of diameter less than $10 \mu \mathrm{m}$ (PM10) were monitored in addition to single-color and four-color digital machines. The cumulative mass concentrations values of $P M_{10}$ for single-color digital machine were in the range from 1.36 to $9.90 \mathrm{\mu g} / \mathrm{m}^{3}$, and they are almost 1.4 and 2.2 times higher compared to the same values for the four-color machine $\left(0.97-4.44 \mathrm{\mu g} / \mathrm{m}^{3}\right)$. The obtained results could be useful for the risk assessment of indoor exposure to suspended $P M_{10}$ particles, and for the creation of printing indoor air quality guidelines of the Republic of Serbia.
\end{abstract}

Key words: digital printing, suspended particulate matter, indoor air quality

\section{INTRODUCTION}

Mass concentration has been one of the most commonly measured aerosol properties of indoor air quality, and the most important one for health and environmental effects. Many of epidemiological data suggesting that elevated levels of suspended particulate matters (PMs) are associated with an array of human health hazards (lowered immune systems, asthma or chronic coughs, even triggering heart attacks, etc.) (Wang et al, 2016). Therefore it is necessarily accurate monitoring data on mass concentration because it's right mass concentrations are the important basis for further calculations (chemical compositions or any specific property, such as isotopic content) (Wang et al, 2015).

PMs are complex mixtures of solid and liquid organic and inorganic substances (sulfate, nitrate, ammonia, sodium chloride, carbon, mineral dust and water). PMs were inhaled in a respiratory system with a potentially harmful effect on human health. Today, concentrations of suspended PMs in ambient air are quantitated based on the measurement of mass concentrations of particles with the diameter less than $10 \mu \mathrm{m}\left(\mathrm{PM}_{10}\right)$ and less than $2.5 \mu \mathrm{m}\left(\mathrm{PM}_{2.5}\right)$ (Vujić et al, 2010). During printing production processes, suspended PMs are produced and have an impact on the immediate environment, and therefore also to technical persons who directly serve these processes. Unfortunately, there is not enough information about indoor air quality during emission of suspended PMs by printing operations in the Republic of Serbia.

In printing techniques which ones using paper as a printing medium, sources of PMs are paper dusting and processes such as the collection, sorting, bonding and cutting of printed and unprinted paper. Dust consists of too short and insufficiently intertwined fibres of paper or filler particles that are not sufficiently bonded to the sheet of paper or are only bound by the action of static electricity. Dust also occurs in a paper who is inexpert circumcising a blunt printing knife in format or rolls (Prica et al, 2017). In digital printing technology, the sources of PMs are dust extraction, treatment processes of printing or unprinted paper and digital printing equipment.

The use of digital printing equipment (laser printers and photocopiers) has grown exponentially over the last decade. Digital printing equipment utilises a photosensitive drum to attract the toner powder and fuse it on the page with a set of rollers that apply high levels of pressure and heat. These toners are emitting particulate matters which are released via the board cooler, rear of the printer, paper tray and toner waste bin (Pirela et al, 2014). Since there is a plethora of epidemiological and toxicological evidence linking exposures to ambient particles with adverse health effects (Zhao et al, 2013) the high levels of PMs emissions have undoubtedly raised concerns about possible toxicity.

The objective of this study is to evaluate the impact of the type of digital machine on increasing of mass concentration of suspended $\mathrm{PM}_{10}$ particles in the ambient air of the digital printing office. The concentration levels of suspended $\mathrm{PM}_{10}$ particles in the ambient air of the digital printing office were monitored during three working weeks (120 hours or 40 hours per week). Also, the detected 
concentrations of the suspended $\mathrm{PM}_{10}$ particles emitted by the examined digital printing machines are compared with the emission limit values according to prescribed domestic and international legal acts.

\section{METHODS}

\subsection{Digital printing office}

During the three working weeks of monitoring suspended $\mathrm{PM}_{10}$ particles, digital printing processes (electrophotographic procedure) were performed on single-color Xerox D95A and the four-color Xerox DocuColor 252 printing machines. The graphic material, offset paper ( $\left.G=80 \mathrm{~g} / \mathrm{m}^{2}\right)$ and cyan, magenta, yellow and black (CMYK) digital toners, manufactured by Xerox, were used. There are two employees in the digital printing office, but as the printing office is used for student education, and 2 to 5 students were present in practice during the monitoring.

\subsection{Analysis of suspended $\mathrm{PM}_{10}$ particles in the ambient air of the digital printing office}

Mass concentrations of suspended $\mathrm{PM}_{10}$ particles in the ambient air of the digital printing office were determined using the standard gravimetric measurement method (SRPS EN 12341: 2015).

According to an SRPS EN 12341: 2015 method for the experiment, the following equipment and materials were used:

- $\quad$ a sampler for analysis of particulate matters (BAGHIRRA s.r.o., Czech Republic),

- an analytical balance (Kern analytical balance, model ABJ-120, Germany),

- $\quad$ filter paper with a diameter of $47 \mathrm{~mm}$ (Whatman, UK) and

- pincette.

The sampling of $\mathrm{PM}_{10}$ suspended particles was carried out by a particulate matter sampler via a $\mathrm{PM}_{10}$ filter paper which was placed on the duraluminum filter holder of the sampler. The masses of the filters paper before and after one hour of sampling were measured on the analytical balance, with an accuracy of $\pm 0.0001 \mathrm{~g}$. Due to the accuracy of the results, do not touch the filter paper with fingers, but only with pincette.

The operational parameters of the sampler for analysis of suspended $\mathrm{PM}_{10}$ particles for one-hour measurements during the three working weeks of monitoring are shown in Table 1.

Table 1: The operational parameters of the sampler for analysis of suspended $P M_{10}$ particles

\begin{tabular}{|l|c|}
\hline \multicolumn{1}{|c|}{ Parameter } & Interval \\
\hline Ambient temperature $\left({ }^{\circ} \mathrm{C}\right)$ & $25-34$ \\
\hline Ambient pressure $(\mathrm{mbar})$ & $1005-1014$ \\
\hline Temperatures of sampler $\left({ }^{\circ} \mathrm{C}\right)$ & $24-32$ \\
\hline Flow $(\mathrm{l} / \mathrm{min})$ & $13.1-15.2$ \\
\hline Flow for $1 \mathrm{~h}(\mathrm{I} / \mathrm{min})$ & $730-963$ \\
\hline
\end{tabular}

\subsection{Calculation of the mass concentration of suspended $\mathrm{PM}_{10}$ particles}

The concentration levels of suspended PM10 particles in the ambient air of the digital printing office were determined according to formula (1) (SRPS EN 12341: 2015):

$$
Q_{P M_{10}}=\frac{m_{2}-m_{1}}{V} \cdot 10^{6}
$$

Where are: $Q_{P M_{10}}$ - the quantity of suspended PM10 particles $\left(\mu \mathrm{g} / \mathrm{m}^{3}\right), \mathrm{m}_{1}$ and $\mathrm{m}_{2}$ - the mass of the filter paper before and after sampling $(\mathrm{g})$, respectively, and $\mathrm{V}$ - the volume of air passed through the device for 1 hour $\left(\mathrm{m}^{3}\right)$.

Daily eight-time values of $\mathrm{PM}_{10}$ particles are calculated by a cumulative compilation of one-hour data updated every hour. Also, mass concentrations of suspended $\mathrm{PM}_{10}$ particles were measured one-hour before the start of the operation of digital machines during sampling. 


\section{RESULTS AND DISCUSSION}

Detected mass concentrations of suspended $\mathrm{PM}_{10}$ particles before operation of digital machines (zero values) during monitoring were in the range from 0.77 to $0.88 \mu \mathrm{g} / \mathrm{m}^{3}$. Zero value show that some particle concentration was left in the air after the ventilation, but also that the particles migrate from the outside air into the ambient air of the printing office, which is not an isolated space. The detected mass concentrations of $\mathrm{PM}_{10}$ particles during the eight-hour operation for the tested machines were reduced by the detected zero value to obtain real mass concentrations.

Variations of minimum and maximum mass concentrations, their cumulative and mean values for suspended $\mathrm{PM}_{10}$ particles during the three working weeks monitoring for a single-color and four-color digital machine are shown in Table 2.

Table 2: Variations of mass concentrations of suspended PM10 particles during three working weeks monitoring for tested digital machines

\begin{tabular}{|l|c|c|c|c|c|c|}
\hline \multicolumn{1}{|c|}{ Data } & \multicolumn{2}{|c|}{ Single-color Xerox D95A } & \multicolumn{3}{c|}{ Four-color DOCUCOLOR 252 } \\
\hline Working week & $1^{\text {st }}$ & $2^{\text {nd }}$ & $3^{\text {rd }}$ & $1^{\text {st }}$ & $2^{\text {nd }}$ & $3^{\text {rd }}$ \\
\hline Total number of measurements & 40 & 40 & 40 & 40 & 40 & 40 \\
\hline MIN $Q_{P M_{10}}\left(\mu \mathrm{g} / \mathrm{m}^{3}\right)$ & 0.11 & 0.36 & 0.19 & 0.11 & 0.11 & 0.10 \\
\hline MAX $Q_{P M_{10}}\left(\mu \mathrm{g} / \mathrm{m}^{3}\right)$ & 1.57 & 1.77 & 0.85 & 0.79 & 0.71 & 0.70 \\
\hline MIN cumulative value of $Q_{P M_{10}}\left(\mu \mathrm{g} / \mathrm{m}^{3}\right)$ & 1.36 & 4.30 & 1.84 & 0.99 & 0.97 & 1.34 \\
\hline MAX cumulative value of $Q_{P M_{10}}\left(\mu \mathrm{g} / \mathrm{m}^{3}\right)$ & 9.90 & 9.66 & 8.05 & 4.44 & 3.76 & 4.25 \\
\hline MIN mean value of $Q_{P M_{10}}\left(\mu \mathrm{g} / \mathrm{m}^{3}\right)$ & 0.17 & 0.54 & 0.23 & 0.12 & 0.12 & 0.17 \\
\hline MAX mean value of $Q_{P M_{10}}\left(\mu \mathrm{g} / \mathrm{m}^{3}\right)$ & 1.24 & 1.21 & 1.01 & 0.56 & 0.47 & 0.53 \\
\hline
\end{tabular}

Analysing the influence of the type of digital machine on increasing the concentration of suspended $\mathrm{PM}_{10}$ particles in the ambient air of the digital printing office, has been found that the significant contribution has single-color (Figure 1a) than the four-color digital machine (Figure 1b). The cumulative and mean values for the single-color digital machine were in the range: from 1.36 to $9.90 \mu \mathrm{g} / \mathrm{m}^{3}$ and from 0.17 to $1.24 \mathrm{\mu g} / \mathrm{m}^{3}$, respectively. The same values for a four-color digital machine are lower than 1.4 to 2.2 times and were in the range: from 0.97 to $4.44 \mu \mathrm{g} / \mathrm{m}^{3}$ (cumulative) and from 0.12 to $0.56 \mu \mathrm{g} / \mathrm{m}^{3}$ (mean value).
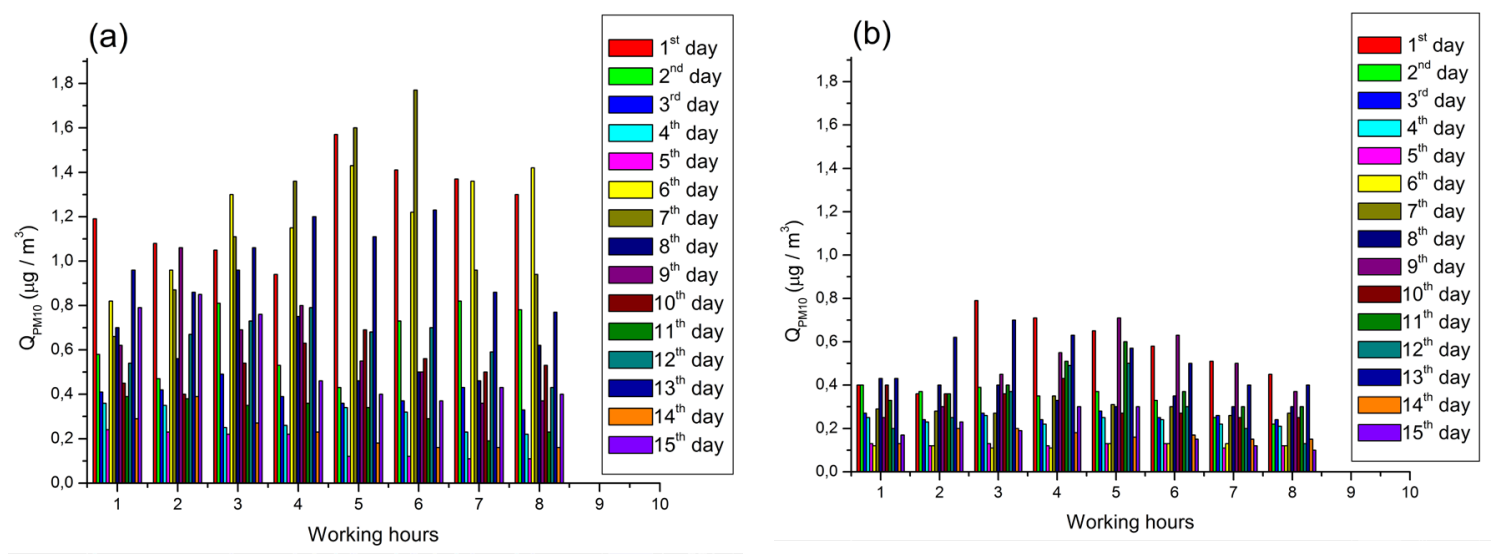

Figure 1: Mass concentrations of suspended $P M_{10}$ particles for eight-hour operation during ten days of monitoring in addition to (a) single-color Xerox D95A and (b) four-color Xerox DocuColor 252 printing machines

According to the manufacturer, during the operation of a digital machine, minimal amounts of paper dust and toner were emitted into the air. Most of the dust generated inside the machine goes through the exhaust gases and is retained on the filters. Dust consists primarily of particles and fibres of the paper and their levels depend on the composition and quality of the paper used. Less than 10 percent of the dust was produced by a toner cartridge (Xerox Corporation, 2017). 
Air protection in Serbia is regulated by the Law on Air Protection ("Sl. glasnik RS", br. 136/09 i 10/2013) and the Regulation on the Conditions for Monitoring and Air Quality Requirements ("SI. glasnik RS", br. 11/2010, 75/2010 i 63/2013) which are harmonized with the EU Directive (Council Directive 1999/30/EC). According to the above mentioned legal acts during the one-hour monitoring, the presence of suspended $\mathrm{PM}_{10}$ particles in the ambient air is not allowed, while for 24 hours the emission limit values are $50 \mu \mathrm{g} / \mathrm{m}^{3}$. The investigated digital office was working only in one shift and for that reason was not conducted monitoring for 24 hours. Based on the highest cumulative values of mass concentrations of suspended $\mathrm{PM}_{10}$ particles of $9.90 \mu \mathrm{g} / \mathrm{m}^{3}$ (single-color machine) and $4.44 \mu \mathrm{g} / \mathrm{m}^{3}$ (four-color machine) and assuming that the printing press operates the same capacity in three shifts, the values within 24 hours would be 29.70 and $13.32 \mu \mathrm{g} / \mathrm{m}^{3}$ respectively. Even three times higher concentrations do not exceed emission limit values $\left(50 \mu \mathrm{g} / \mathrm{m}^{3}\right)$ for 24 hours according to the above mentioned legal acts.

\section{CONCLUSION}

The monitoring conducted during the three working weeks showed that the digital printing process contributes to the quality of ambient air through the emission of suspended PM10 particles. Comparing the influence of the type of digital machine on increasing the concentration of suspended $\mathrm{PM}_{10}$ particles in the ambient air of the digital printing has been found that the more significant contribution has single-color regarding the four-color machine. The maximum cumulative values for the single-color digital machine are in the interval from 8.05 to $9.90 \mu \mathrm{g} / \mathrm{m}^{3}$ and almost 2.2 times higher than the same value for a four-color machine. Also, the maximum mean value during monitoring is 2.2 times higher for singlecolor compared to the four-color digital machine.

It is noticed that there is no form by which the concentration of suspended PM10 particles for eight-hour hours is changed because the operation of digital machines is semi-automatic and depends on the organisation of the operator and the printing process circulation.

The Regulation of the Republic of Serbia and the EU Directive (2008/50/EC) do not define the emission limit values of suspended $\mathrm{PM}_{10}$ particles during the eight-hour working hours. Therefore, the obtained results are the starting point in the future continuous monitoring of suspended $\mathrm{PM}_{10}$ particles in digital but also in other printing techniques to get relevant data which would be supplemented by the laws of the Republic of Serbia.

\section{REFERENCES}

[1] Institut za standardizaciju Srbije, SRPS EN 12341:2015 Vazduh ambijenta - Standardna gravimetrijska metoda merenja za određivanje PM10 ili PM2,5 masene koncentracije suspendovanih čestica, Institut za standardizaciju Srbije, 2015.

[2] Pirela, S.V., Pyrgiotakis, G., Bello, D., Thomas, T., Castranova, V., Demokritou, P.: "Development and characterization of an exposure platform suitable for physico-chemical, morphological and toxicological characterization of printer-emitted particles (PEPs)“, Inhalation Toxicology, 26(7), 400-408, 2014. doi: 10.3109/08958378.2014.908987.

[3] Prica, M., Adamović, S.: "Grafički materijali“, (FTN Izdavaštvo, Novi Sad, 2017).

[4] Službeni glasnik ("Sl. glasnik RS", br. 11/2010, 75/2010 i 63/2013): Uredba o uslovima za monitoring i zahtevima kvaliteta vazduha, Službeni glasnik, 2013.

[5] Službeni glasnik ("Sl. glasnik RS", br. 136/09 i 10/2013): Zakon o zaštiti vazduha, Službeni glasnik, 2013.

[6] The European Parliament and The Council Of The European Union, "Council Directive 1999/30/EC", Official Journal of the European Communities, 42, 1, 1999.

[7] The European Parliament and The Council Of The European Union, „Directive 2008/50/EC of the European Parliament and of the Council of 21 May 2008 on ambient air quality and cleaner air for Europe", Official Journal of the European Union, 51, 1, 2008.

[8] Vujić, B.B., Milovanović, D.B., Ubavin, D.M.: "Analiza koncentracionih nivoa čestičnih materija (PM10, ukupnih suspendovanih čestica i čađi) u Zrenjaninu“, Hemijska industrija, 64(5), 453-458, 2010. doi: 10.2298/HEMIND100323041V.

[9] Wang, P., Cao, J.-J., Shen, Z.-X., Han, Y.-M., Lee, S.-C., Huang, Y., Zhu, C.-S., Wang, Q.-Y., Xu, H.-M., Huang, R.-J.: "Spatial and seasonal variations of PM2.5 mass and species during 2010 in Xi'an, China", Science of the Total Environment, 508, 477-487, 2015. doi: 10.1016/j.scitotenv.2014.11.007. 
[10] Wang, Y., Yang, W., Han, B., Zhang, W., Che, M., Bai Z.: "Gravimetric analysis for PM2.5 mass concentration based on year-round monitoring at an urban site in Beijing", Journal of Environmental Sciences, 40, 154-160, 2016. doi: 10.1016/j.jes.2015.09.015.

[11] Xerox Corporation, The Safety of Xerox Products, Xerox, 2017, URL: https://www.xerox.com/downloads/usa/en/e/environment_safetyfacts.pdf (last request: 2018-06-21.).

[12] Zhao, J., Gao, Z., Tian, Z., Xie, Y., Xin, F., Jiang, R., Kan, H., Song, W.: "The biological effects of individual-level PM2.5 exposure on systemic immunity and inflammatory response in traffic policemen", Occupational and Environmental Medicine, 70(6), 426-431, 2013. doi: 10.1136/oemed-2012-100864.

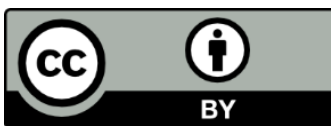

(C) 2018 Authors. Published by the University of Novi Sad, Faculty of Technical Sciences, Department of Graphic Engineering and Design. This article is an open access article distributed under the terms and conditions of the Creative Commons Attribution license 3.0 Serbia (http://creativecommons.org/licenses/by/3.0/rs/). 